\title{
TWO CASES OF MARROW FAILURE WITH MASSIVE MARROW PLASMOCYTOSIS SIMULATING MYELOMATOSIS
}

\author{
BY \\ W. D. NICOLL, A. J. WATSON, AND J. W. WHITELAW \\ From the Ayrshire Area Laboratory Service and the University Departments of Pathology and \\ Haematology, Western Infirmary, Glasgow
}

(RECEIVED FOR PUBLICATION MAY 20, 1958)

It is sometimes difficult to assess the significance of an increased proportion of plasma cells in the bone marrow, although it is generally accepted that figures greater than $2 \%$ are outside the normal range (Wintrobe, 1956). An obvious increase may occur either as a simple reactive phenomenon accompanying a variety of diseases and without known significance, or as a disease sui generis in myelomatosis. In general a reactive increase is relatively slight whereas in myelomatosis the increase is gross and confirmation of the diagnosis will almost certainly be obtainable radiologically or biochemically. Difficulty in assessment is commonly experienced when the increase of plasma cells in the marrow is only moderate, but it may not be generally realized that this difficulty may persist when there is a marrow plasmocytosis of $60 \%$ or $70 \%$. Such a finding, even when accompanied by a greatly increased E.S.R. and gross hyperglobulinaemia, does not always constitute evidence of myelomatosis, for these changes may also be essentially reactive in nature. Two illustrative examples are presented.

\section{Case Reports}

Case 1.-A woman aged 61 died in the Royal Mental Hospital, Glasgow, on December 17, 1955. During the previous six years she had been treated for chronic anaemia by her own doctor with iron and injections of liver extract. These raised the haemoglobin level from $50 \%$ (7.4 g. per $100 \mathrm{ml}$.) to $90 \%$ $(13.0 \mathrm{~g}$. per $100 \mathrm{ml}$.), as estimated by the alkaline haematin method $(100 \%=14.8 \mathrm{~g}$. per $100 \mathrm{ml}$.). When treatment was stopped her condition invariably relapsed. No detailed haematological examination was performed during this period, but it is known that the white cell count was within normal limits.

During the last year of her life she complained of increasing deafness for which she was treated with dry thyroid, 2 grains daily, for a period of 10 weeks. After two months of this treatment she began to suffer from mild depression followed by a period of excite- ment. Two weeks after the onset of these emotional disturbances she was admitted to hospital (December 3,1955 ), where it was considered that she was suffering from an attack of mania possibly complicated by confusion secondary to some toxic process. Clinical examination at this time disclosed no abnormality other than anaemia.

Laboratory Findings.-Blood examination on admission gave the following results:- $\mathrm{Hb} 51.5 \%$ (7.6 g. per $100 \mathrm{ml}$.), P.C.V. $22 \%$, M.C.H.C. $34.6 \%$, W.B.C. 1,850 per c.mm., and reticulocytes $2 \%$ of the R.B.C. Within a few days the leucocyte count had fallen to 750 per c.mm. and blood films showed marked rouleaux formation with a severe leucopenia predominantly affecting the neutrophils; no primitive white cells or plasma cells were present, and their absence was confirmed by examination of a buffy coat preparation; platelets were in normal numbers. Smears and histological sections of the sternal marrow were examined (Cappell, Hutchison, and Smith, 1947). Although the fragments were in general rather more cellular than normal this increase in cellularity was less than was to be expected in view of the pronounced anaemia (Fig. 1); megakaryocytes were present in normal numbers; $75 \%$ of the cells were plasma cells with a few young forms showing definite nucleoli, but most were of mature type (Fig. 2); a marked reduction in the number of both red and white cell precursors was evident. The picture was that of a severe hypoplasia of the blood-forming elements with gross secondary plasmocytic infiltration. The E.S.R. was considerably raised. The serum albumin was $2.29 \mathrm{~g}$. per $100 \mathrm{ml}$. and the serum globulin 3.29 g. per $100 \mathrm{ml}$., giving an albumin-globulin ratio of 0.69. Bence-Jones proteinuria was not present.

Progress. - Nine days after admission she developed acute bronchopneumonia which failed to respond to treatment with penicillin. A slow drip of 2 pints of fresh Group $O$ blood brought no improvement, and she died five days later.

Post-mortem Findings.-There was considerable rarefaction of the bodies of the lumbar and lower thoracic vertebrae and the marrow was much paler than normal. The sternal marrow was pink; a small 


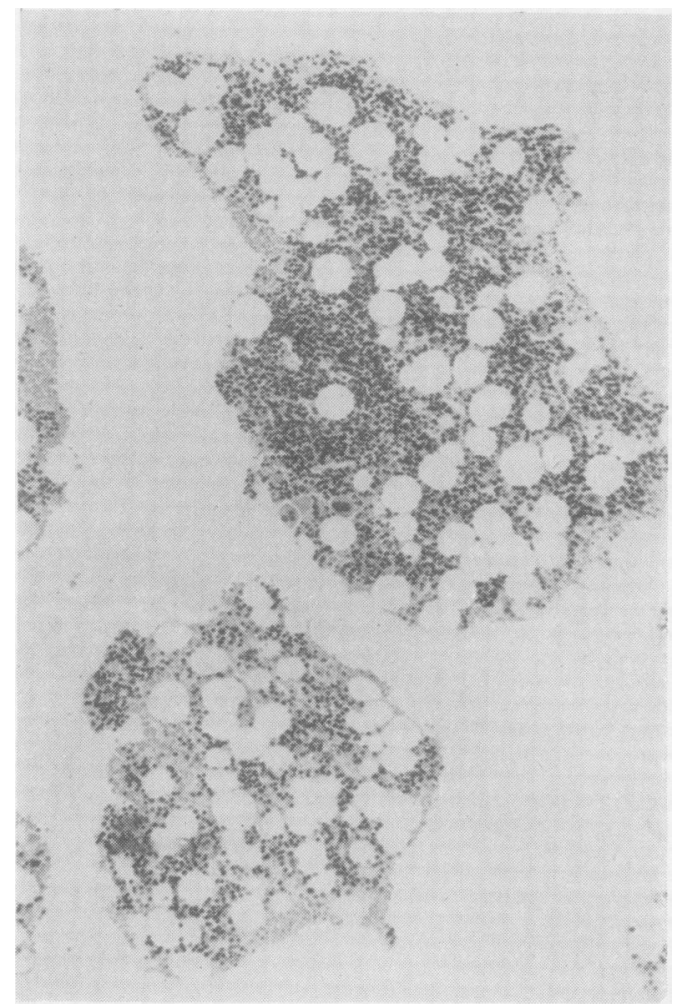

FIG. 1.-Case 1. Low-power view of the histological section of the sternal marrow biopsy showing the relatively slight increase in cellularity. Haematoxylin and eosin $\times 70$.

amount of reddish marrow was present at the upper end of the shaft of the right femur, and the remainder of the marrow cavity was filled with yellow fatty marrow in which there were occasional small red foci. No nodules of tumour were evident in any of these marrow spaces. Microscopical examination of marrow from the sternum, vertebrae, and upper end of the femur revealed an almost complete absence of haemopoietic elements, the great majority of the cells present in the generally fatty marrow being plasma cells. The lungs were very oedematous; the left lower lobe was intensely congested and covered by fibrin; vomitus was present in the air passages. Microscopy showed an acute haemorrhagic bronchopneumonia characterized by almost complete absence of inflammatory cells. Lentil seeds in many of the bronchioles (Head, 1956), and considerable digestion of the lung parenchyma, provided definite evidence of aspiration of vomitus (Fig. 3). The liver $(1,850$ g.) showed centrilobular congestion and necrosis. The spleen $(360 \mathrm{~g}$.) contained an unusually large number of plasma cells. The thyroid gland was of normal size, and although microscopy showed inactivity the appearances were not those seen in myxoedema.

Case 2.-A man aged 72 was admitted to Heathfield Hospital, Ayr, on September 27, 1956, with a pustular, crusted eruption over the lips and lower jaw, 을 apparently a sensitivity reaction following treatment $\underset{\vec{\omega}}{\vec{\rho}}$ for parotitis with sulphonamides and penicillin.

Clinical Findings.-He was pale, obese, and slightly 응 icteric. No lymph nodes were palpable in the axillae $\frac{\bar{\sigma}}{\bar{\omega}}$ or groins, but the cervical lymph nodes could not be $\frac{\sigma}{\sigma}$ adequately examined because of the skin condition. $\varrho$ The tongue was moist and clean, but the fauces were not seen as the mouth could not be fully opened. There was a tachycardia of 114 per minute, with a respiratory rate of 26 per minute and a blood pressure $\overrightarrow{\vec{\omega}}$ of $100 / 50 \mathrm{~mm}$. $\mathrm{Hg}$. The temperature at this time $\underset{\sigma}{\omega}$ was normal, though an intermittent pyrexia of up to $101^{\circ} \mathrm{F}$. appeared later. There was marked sacral ? and slight ankle oedema and some overfilling of the $\overrightarrow{\vec{H}}$ neck veins was noted. The spleen was not enlarged. in No other abnormality was found on clinical examination.

Laboratory Findings.-The haemoglobin was $21 \%$ 을 (3.1 g. per $100 \mathrm{ml}$.), the P.C.V. $10 \%$, the M.C.H.C. $\vec{c}$ $31 \%$, the reticulocytes $0.25 \%$ of the red cells, and the $\mathbb{D}$ W.B.C. 800 per c.mm. The film revealed marked rouleaux formation and a moderate degree of anisocytosis; platelets were present in normal numbers; neutrophil polymorphs formed only $9 \%$ (72 per

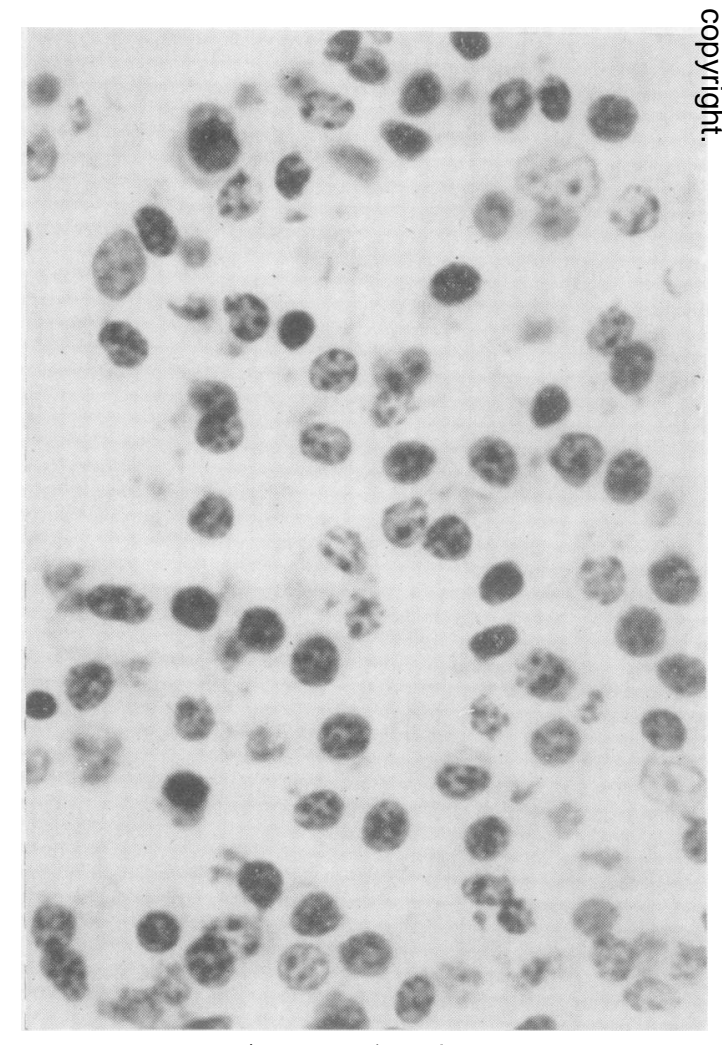

FIG. 2.-Case 1. High-power view of marrow section showing numerous plasma cells and marked reduction in normal marrow elements. Haematoxylin and eosin $\times 1,140$. 


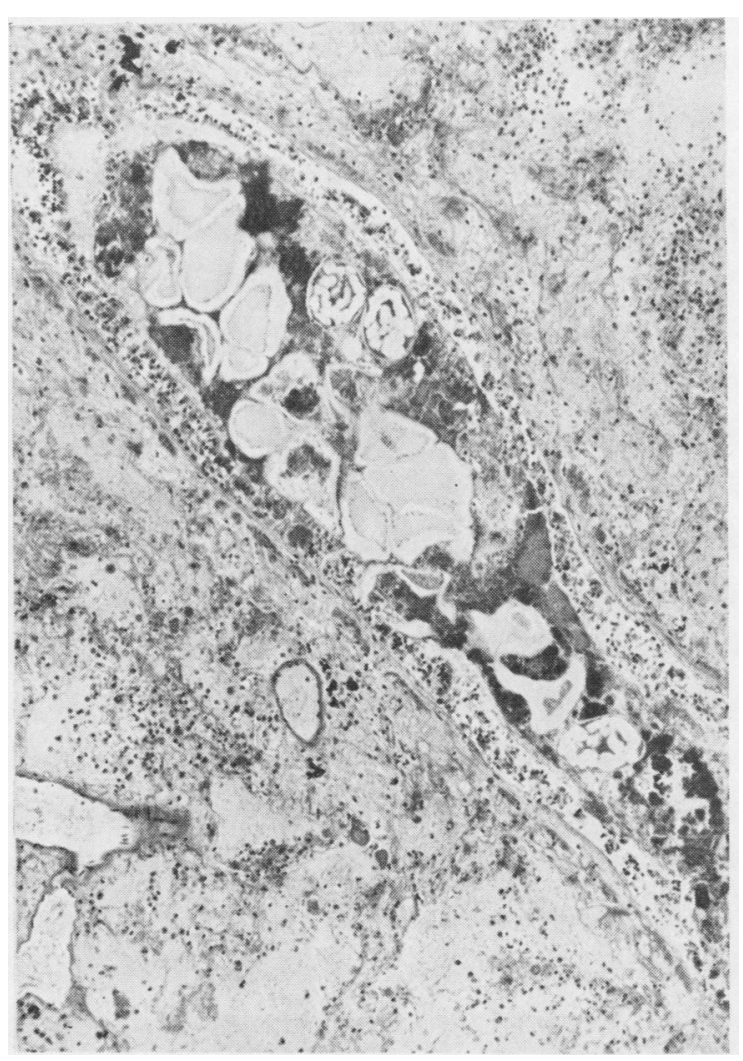

FIG. 3.-Case 1. Vomitus, including lentil seeds, in bronchiole. Note sparse cellular infiltration in adjacent consolidated lung. Haematoxylin and eosin $\times 72$.

c.mm.) of the total white cells. Smears of the sternal marrow showed a pronounced infiltration by plasma cells $(55 \%)$ and to a lesser extent by lymphocytes (Fig. 4). The plasma cells were for the most part of mature type, but a small proportion appeared atypical and occasional vacuolated binucleate forms were noted. Normal marrow elements were markedly reduced in numbers: apart from a few rather small atypical myeloblasts, occasional neutrophil polymorphs and metamyelocytes were the only myeloid elements present ; the erythroid series was represented by small numbers of normoblasts at varying stages of development, the majority being late fully haemoglobinized forms; megakaryocytes were present, but in small numbers. Histological examination of the marrow fragments showed that they were of normal cellularity, but in view of the severe anaemia and the high proportion of plasmocytes this was taken to indicate hypoplasia of the normal marrow elements.

The serum proteins were $6.9 \mathrm{~g}$. per $100 \mathrm{ml}$. (albumin $3.2 \mathrm{~g}$. per $100 \mathrm{ml}$. and globulin $3.7 \mathrm{~g}$. per $100 \mathrm{ml}$.), with an albumin-globulin ratio of 0.87. Electrophoresis showed an increase in the gamma globulin fraction. The serum calcium, phosphorus, and alkaline phosphatase levels were normal. The serum bilirubin was $7.4 \mathrm{mg}$. per $100 \mathrm{ml}$. and serum uric acid $3.5 \mathrm{mg}$. per $100 \mathrm{ml}$. Bence-Jones proteinuria was absent.

Radiography of the skull and long bones showed no evidence of myelomatosis.

Course and Treatment.-For the first two weeks the patient's condition remained precarious and he was disorientated and delirious. Shortly after admission he was given a transfusion of 4 pints of fresh blood which raised the haemoglobin to $47 \%$ (6.9 g. per $100 \mathrm{ml}$.). Intravenous terramycin and intramuscular penicillin therapy was instituted and he was also given pentose nucleotide, $10 \mathrm{ml}$. intramuscularly twice daily. Urinary retention had to be relieved by an indwelling catheter, and an infection of the urinary tract which followed proved most resistant to antibiotic therapy including streptomycin and chloramphenicol. On the twelfth day after admission 2 further pints of whole blood were transfused, and on the fourteenth day the haemoglobin was $61 \%(9.0 \mathrm{~g}$. per $100 \mathrm{ml}$.). During this two-week period the white count varied from 500 to $1,200 /$ c.mm. with up to $20 \%$ granulocytes ; on several occasions a few plasma cells were seen in the

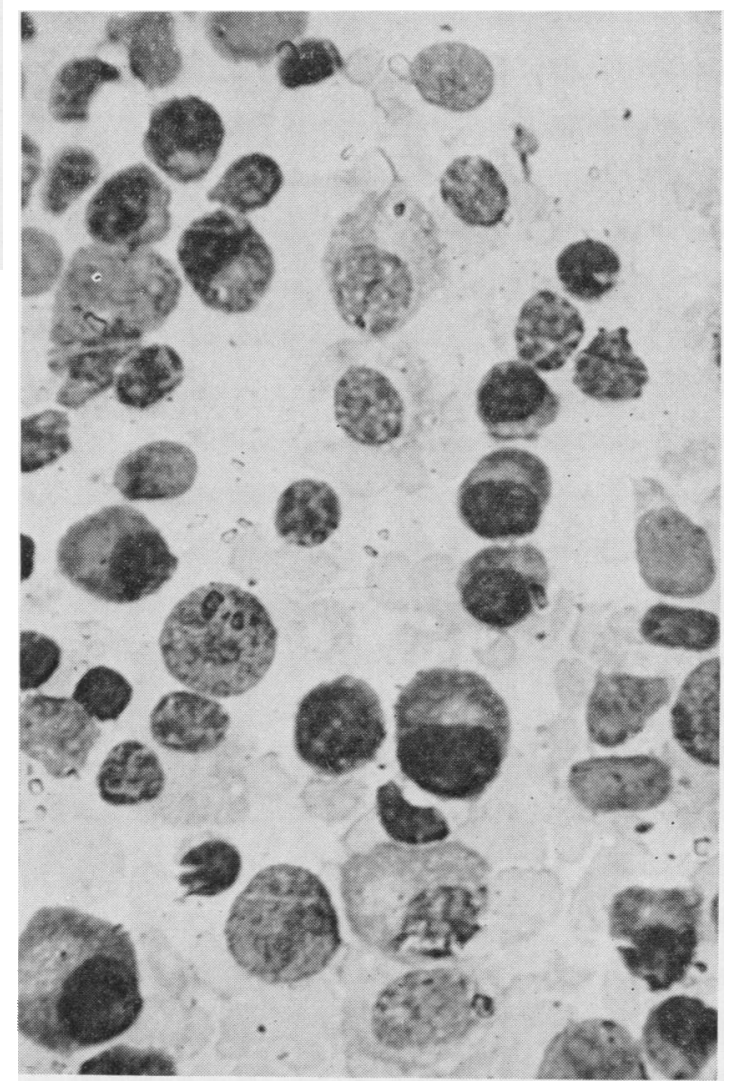

FIG. 4.-Case 2. Initial marrow smear showing great increase in the proportion of plasma cells relative to other marrow elements
which are considerably diminished. Leishman $\times 800$. 
peripheral blood; reticulocytes were constantly less than $1 \%$ of the red cells. On the fifteenth day sternal puncture was repeated. The findings were essentially unchanged except for a slight fall in the number of plasma cells and a corresponding rise in the number of erythroid and myeloid elements.

From this date the patient's condition began to improve slowly but progressively. The white cell count slowly rose and this was accompanied by a gradual increase in the proportion of granulocytes and by a low reticulocytosis which reached a maximum of $4.5 \%$ on the 26th day. By this time the white count had reached $5,200 / \mathrm{c} . \mathrm{mm}$. with $78 \%$ granulocytes; there was a prominent shift to the left and the frequent juvenile forms, metamyelocytes, and even myelocytes, indicated considerable marrow activity. Occasional normoblasts were also noted in the blood film. A further marrow puncture showed a continuing increase in the number of normal marrow elements, with a diminishing plasma cell content.

The rise in the white count continued: on the 33rd day it reached $15,300 / \mathrm{c} . \mathrm{mm}$. and for the remainder of the patient's stay in hospital it did not fall below $11,000 / \mathrm{c} . \mathrm{mm}$. The haemoglobin responded more

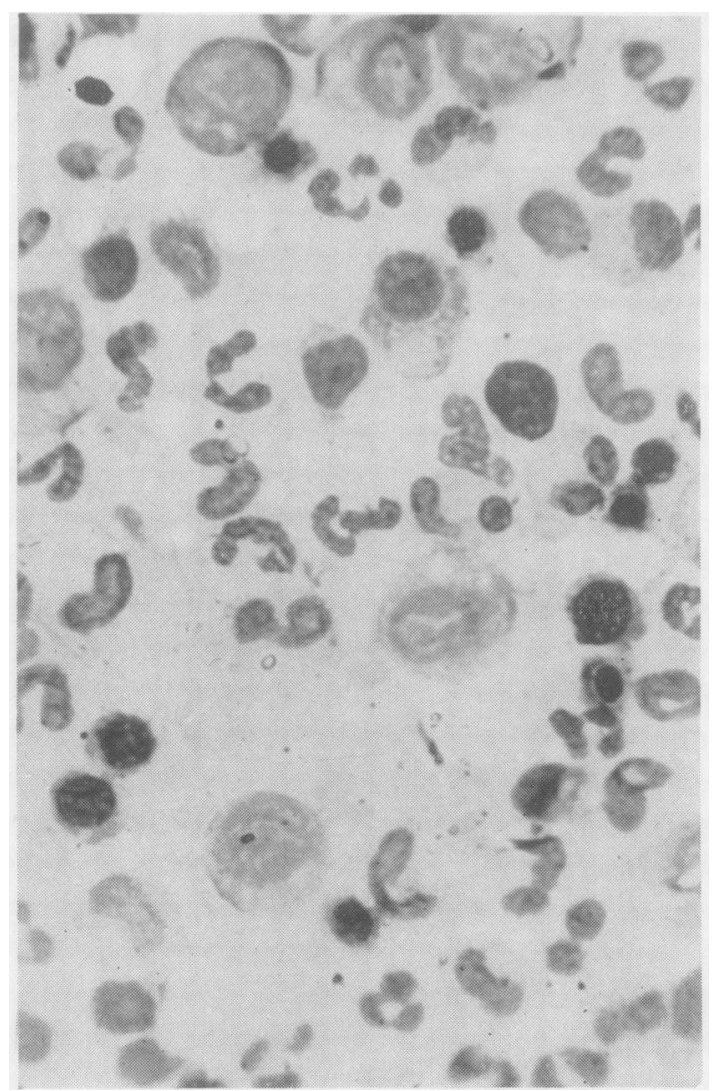

Fig. 5.-Case 2. Marrow smear on 55th day of illness showing return to normal with only scanty plasma cells and numerous segmented neutrophils. Leishman $\times 800$. slowly and several blood transfusions were required at short intervals to maintain it at from 54 to $61 \%$ $(8.0$ to $9.0 \mathrm{~g}$. per $100 \mathrm{ml}$.). These blood findings were considered to be a result of the urinary tract infection, for a raised blood urea of up to $130 \mathrm{mg}$. per $100 \mathrm{ml}$. indicated some impairment of renal function.

On the 55th day the bone marrow had almost returned to normal ; it was of average cellularity and contained only $2 \%$ plasma cells ; no abnormality was noted in the myeloid series apart from a slight eosinophilia, and segmented neutrophils were numerous (Fig. 5). The serum protein pattern also showed a progressive improvement, the albumin-globulin ratio returning to normal with a gradual fall in the gamma globulin.

On the 77th day the patient was transferred to Ballochmyle Hospital, Mauchline, for plastic repair of a skin defect of one thigh following a large abscess which had developed at the site of the pentose nucleotide injections. During the next two months further blood transfusions were given on two occasions to hasten the return of the haemoglobin to normal. Renal function gradually improved with an accompanying fall in the blood urea. When discharged on February 15, 1957, with his leg soundly healed, peripheral blood and blood urea concentrations were normal and electrophoresis of serum gave $\delta$ a normal protein pattern. $\mathrm{He}$ was still well, with normal laboratory findings, when last seen in April 1957.

\section{Discussion}

Both these patients presented with severe anaemia and granulocytopenia amounting almost to agranulocytosis. When further investigation showed a massive infiltration of the bone marrow by plasma cells, rouleaux formation, a high E.S.R., and hyperglobulinaemia, a diagnosis of myelomatosis was seriously considered. Anaemia is common in this condition and may indeed be the presenting feature ; also leucopenia was present in $40 \%$ of the cases reviewed by Snapper, Turner, and Moscovitz (1953). While the plasma cell infiltration in the marrow smears from these patients was heavy, the great majority were of normal mature type, and although there were a few atypical and immature cells these were not more numerous than is commonly found in secondary plasmocytosis. Although some authorities hold that the so-called myeloma cell has characteristics which distinguish it from the plasma cell (Wintrobe, 1956 ; Snapper et al., 1953) histological examination of the marrow particles had been found here to be more helpful and reliable in resolving the diagnostic problem. In myelomatosis there is a spurious appearance of hyperplasia, but the replacement of the fat is actually due to infiltration by plasma cells which occur in clumps and sheets while the usual 
marrow elements are not obviously increased in amount. In secondary plasmocytosis, on the other hand, the overall cellularity is not grossly increased, for plasma cells have merely taken the place of the normal marrow elements as in our own two cases. In addition, Bence-Jones protein was absent from the urine of both patients and there were no skeletal changes at necropsy in Case 1 nor radiologically in Case 2 . The normal uric acid level in Case 2 provided further evidence against myelomatosis, for the serum uric acid is almost constantly raised in myelomatosis whereas in non-myeloma cases it is usually within normal limits if renal function is unimpaired. Finally, in Case 2, conclusive evidence for the benign nature of the infiltration was afforded by the progressive disappearance of plasma cells as recovery took place.

Secondary plasmocytosis, sometimes accompanied by a plasma cell infiltration of other organs, has been recorded in a great variety of apparently unrelated disorders including acute rheumatism, rheumatoid arthritis, liver disease, Hodgkin's disease, and carcinoma (see Clark and Muirhead, 1954). The proportion of plasma cells is often considerable (Fadem, 1952), the highest proportions hitherto recorded being $55 \%$ in a patient who was hypersensitive to sulphonamides (Wolf and Worken, 1954), and 60.2\% in a patient with agranulocytosis of aplastic type (Paris and Bakke, 1956). In one of the cases described here there was an even greater reactive plasmocytosis than in either of these.

An altered serum protein pattern and a raised E.S.R. usually accompany any considerable degree of secondary marrow plasmocytosis (Clark and Muirhead, 1954), and, conversely, it has been found that patients with an altered pattern usually have some marrow plasmocytosis (Bing and Plum, 1937). Some authorities speak of a fairly close correlation between the degree of alteration in the pattern and the extent of the marrow plasmocytosis (Bing and Plum, 1937; Jarrold and Vilter, 1949; Clark and Muirhead, 1954), but others have failed to confirm this (Berlin, Wallace, and Meyer, 1950), probably because the marrow plasmocytosis does not necessarily reflect the infiltration in other organs such as the spleen (Paris and Bakke, 1956). The usual alteration in plasma proteins is an increase in the gamma globulin, but it may not be discerned unless electrophoresis is carried out, or when detected it may be accepted as evidence of myelomatosis.

The occurrence of serum protein changes in secondary plasmocytosis emphasizes the close relation between plasma cells, the serum protein, and antibodies (Bjørneboe, Gormsen, and Lundquist, 1947 ; Fagraeus, 1948). It is now almost universally accepted that plasma cells, or more probably their precursors, are the source of antibodies which constitute a significant fraction of the gamma globulins. This hypothesis clarifies the significance of marrow plasmocytosis and its accompanying serum protein change in a great variety of conditions. An infective or allergic aetiology has been postulated for many of the diseases associated with marrow plasmocytosis, and in these the plasmocytosis may represent a response to some bacterial or other antigen while the altered serum protein pattern reflects the output of antibodies by the plasma cells. It is an interesting speculation whether the more marked degrees of plasmocytosis seen in agranulocytosis and in hypoplasia or aplasia of the marrow may indicate an excessive production of antibodies in an attempt to compensate for the lack of protective granulocytes.

\section{Summary}

Two cases are reported in which marrow hypoplasia was associated with a gross secondary infiltration of the marrow by plasma cells and an alteration in the serum protein pattern.

These cases are used to exemplify the difficulty which may arise in differentiating between reactive plasmocytosis and myelomatosis, and the value of the histological examination of marrow fragments in such cases is emphasized.

The relationship between marrow plasmocytosis and changes in the serum protein pattern is discussed.

We wish to thank Dr. Angus MacNiven, Physician Superintendent of the Glasgow Royal Mental Hospital, and Dr. R. Hill, consultant physician, Heathfield Hospital, Ayr, for access to the clinical records of Cases 1 and 2 respectively. The photomicrographs were taken by Mr. G. Kerr.

\section{REFERENCES}

Berlin, I., Wallace, S. L., and Meyer, L. M. (1950). Arch. intern. Med., $85,144$.

Bing, J., and Plum, P. (1937). Acta med. scand., 92, 415. Bjørneboe, M., Gormsen, H., and Lundquist, F. (1947). J. Immunol.,

55, 121. F., Hutchison, H. E., and Smith, G. H. (1947). Brit. med. J., 1, 403.

Clark, H., and Muirhead, E. E. (1954). Arch. intern. Med., 94, 425.

Fadem, R. S. (1952). Cancer, 5, 128.

Fagraeus, A. (1948). Acta med. scand., 130, Suppl. 204, 3.

Head, Mary A. (1956). J. clin. Path., 9, 295.

Jarrold, T., and Vilter, R. W. (1949). J. clin. Invest., 28, 286.

Paris, L., and Bakke, J. R. (1956). Amer. J. clin. Path., 26, 1044.

Snapper, I., Turner, L. B., and Moscovitz, H. L. (1953). Multiple Myeloma. Grune and'Stratton, New York.

Wintrobe, M. M. (1956). Clinical Hematology, 4th ed. Lea and Febiger, Philadelphia.

Wolf, J., and Worken, B. (1954). Amer. J. Med., 16, 746. 